\title{
Honoré de Balzac, La Ricerca dell'Assoluto
}

\section{Marco Stupazzoni}

\section{(2) OpenEdition}

\section{Journals}

\section{Edizione digitale}

URL: http://journals.openedition.org/studifrancesi/500

DOI: 10.4000/studifrancesi.500

ISSN: 2427-5856

\section{Editore}

Rosenberg \& Sellier

\section{Edizione cartacea}

Data di pubblicazione: 1 aprile 2015

Paginazione: 161

ISSN: 0039-2944

\section{Notizia bibliografica digitale}

Marco Stupazzoni, « Honoré de Balzac, La Ricerca dell'Assoluto », Studi Francesi [Online], 175 (LIX | I) |

2015, online dal 01 avril 2015, consultato il 18 septembre 2020. URL : http://journals.openedition.org/ studifrancesi/500 ; DOI : https://doi.org/10.4000/studifrancesi.500

\section{Questo documento è stato generato automaticamente il 18 settembre 2020.}

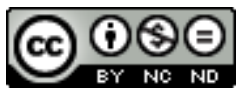

Studi Francesi è distribuita con Licenza Creative Commons Attribuzione - Non commerciale - Non opere derivate 4.0 Internazionale. 


\title{
Honoré de Balzac, La Ricerca dell'Assoluto
}

\author{
Marco Stupazzoni
}

\section{NOTIZIA}

HONORÉ DE BALZAC, La Ricerca dell'Assoluto, traduzione di Paolo CARBONINI, Milano, Quintoelemento Editore, 2013, «Arco Giallo», pp. 313.

1 La Recherche de l'Absolu si annovera senza alcun dubbio tra i titoli più prestigiosi della Comédie humaine: la varietà e la singolarità dei motivi tematici sviluppati nel romanzo, fanno, di quest'opera, contemporaneamente uno studio privato, una scena di provincia e un romanzo filosofico. La straordinaria ricchezza di questo testo, il solo grande romanzo della Comédie humaine che abbia uno scienziato per protagonista e che sia stato ambientato nella cornice storico-sociale della civiltà fiamminga, induce a considerare La Recherche de l'Absolu come un momento di raccordo, sotto la prospettiva esteticoletteraria, tra le Études de mours e le Études philosophiques. Pubblicato, in prima edizione, nel settembre 1834 come scène de la vie privée, il romanzo troverà la sua definitiva collocazione tra le Études philosophiques nel 1846. L'edizione originale (1834) e la seconda edizione separata del 1839 presentavano una suddivisione dell'opera prima in sette e poi in quattro capitoli: questa strutturazione del testo in capitoli sarà definitivamente abbandonata da Balzac nell'edizione Furne del 1846. Ci risulta pertanto difficilmente comprensibile la scelta editoriale, relativa a questa edizione italiana del romanzo filosofico balzachiano, di presentare il testo dell'opera suddiviso in trentadue capitoli non titolati. 